Original Research Paper

\title{
Pendampingan Pengembangan Komoditas Hortikultura Unggulan di Dataran Medium Desa Stiling, Lombok Tengah
}

\author{
M. Sarjan ${ }^{1 *}$, Aluh Nikmatullah², Mery Windarningsih ${ }^{2}$, Agus Purbatin Hadi ${ }^{3}$

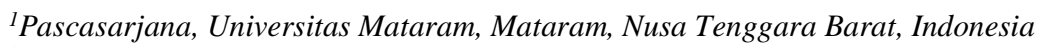 \\ ${ }_{2}^{2}$ Program Studi Agroekoteknologi, Fakultas Pertanian, Universitas Mataram, Mataram, Nusa Tenggara Barat, Indonesia \\ ${ }^{3}$ Program Studi Ilmu Komunikasi, Universitas Mataram,Mataram, Nusa Tenggara Barat, Indonesia
}

DOI: https://doi.org/10.29303/jpmpi.v4i2.644

Sitasi: Sarjan, M., Nikmatullah, A., Windraningsih, M., \& Hadi, A. P. (2021). Pendampingan Pengembangan Komoditas Hortikultura Unggulan di Dataran Medium Desa Stiling, Lombok Tengah. Jurnal Pengabdian Magister Pendidikan IPA, 4(2)

\section{Article history}

Received: 03 Februari 2021

Revised: 08 Maret 2021

Accepted: 10 April 2021

*Corresponding Author:

M. Sarjan, Pascasarjana,

Universitas Mataram, Mataram,

Nusa Tenggara Barat,

Indonesia;

Email: msarjan@unram.ac.id
Abstract: Di wilayah Lombok Tengah sudah mengembangkan berbagai tanaman buah, holtikultura dan beberapa tanaman unggulan lokal di dataran rendah. Sementara dataran medium yang mempunyai kekhasan tersendiri belum dikembangkan terutama untuk budidaya tanaman tertentu seperti kentang, wortel, paprika, bawang putih dan mentimun jepang yang sementara ini hanya ditanaman di dataran tinggi Sembalun. Oleh karena itu pada kegiatan ini dilakukan pendampingan budidaya tanaman tersebut di dataran medium Stiling, Kecamatan Batukliang Utara, Lombok tengah. Metode yang digunakan pada kegiatan ini adalah metode action riset dengan melibatkan kelompok tani selama kegiatan yang diawali dengan penyuluhan teknis budidaya, dilanjutkan dengan kegaiatan penanaman kentang, wortel, paprika, bawang putih dan mentimun jepang. Hasil pendampingan ini menunjukan Kegiatan Pendampingan Pengembangan Komoditas Hortikultura di dataran Medium Desa Stiling, Lombok Tengah sangat didukung oleh pemangku Kebijakan, Kepala Dinas Pertanian dan oleh Kelompok Tani setempat. Tanaman Kentang, wortel, bawang putih, paprika dan mentimun jepang dapat tumbuh baik di dataran medium Stiling, Lombok Tengah. Petani peserta telah mendapatkan pengetahuan dan keterampilan teknik budidaya tanaman yang dicoba pada kegiatan ini yaitu budidaya kentang, wortel, bawang putih, mentimun jepang dan paprika. Untuk meningkatkan hasil guna dari pendampingan ini disarankan perlu dukungan yang pendampingan dari pihak PEMDA Lombok Tengah agar kegiatan pengembangan komoditas hortikultura unggulan dataran medium dapat berlanjut sesuai dengan harapan para petani. Perlu mempertimbangkan saat tanam yang tepat untuk penanaman kempat komoditas yang ingin dikembangkan di lokasi kegiatan, dan sesuai dengan karakteristi musim setempat sebaiknya memulai penanaman pada ahir musim hujan atau sekitar bulan Maret/April Disarankan untuk memperhatikan secara serius masalah ganguan hama dan penyakit tanaman yang sering menjadi kendala dalam budidaya komoditas hortikultura (terutama kentang, timun jepang dan bawang putih) dan dilakukan pengendalian yang tepat dan efektif berdasarkan prinsip Pengelolaan Hama Terpadu. Diharapkan hasil kegiatan ini akan meningkatkan pendapatan petani dan masyarakat sekitar, di samping untuk meningkatkan kenekaragaman homoditas hortikultura potensial di dataran medium sebagai alternative usaha tani di kawasan agrowisata Lombok Tengah. Komoditas unggulan seperti kentang, wortel dan paprika diharapkan menjadi andalan untuk dipasarkan di kawasan wisata lainnya seperti di pantai Selatan Mandalika.

Keywords: Komoditas Unggulan; Dataran medium; Desa Stiling 


\section{Pendahuluan}

Indonesia sebagai negara agraris memiliki kekayaan alam terutama sumber daya hayati tropis yang sangat beragam, yang jika dikelola dengan tepat, akan mampu diandalkan tidak hanya sebagai kekuatan perekonomian nasional secara makro, tetapi juga mempunyai peluang besar sebagai sumber pertumbuhan baru sektor pariwisata. Komoditas pertanian (mencakup tanaman pangan, hortikuoltura, perkebunan, kehutanan, peternakan dan perikanan) dengan keragaman dan keunikan yang bernilai tinggi serta diperkuat oleh kekayaan kultural yang sangat beragam mempunyai daya tarik kuat sebagai agrowisata. Kabupaten Lombok Tengah memiliki beberapa daerah tujuan wisata, dan masing-masing berusaha mengembangkan potensi wisata yang ada di wilayahnya. Beberapa wilayah seperti Kecamatan Bayan, Gangga, Pemenang di Kabupaten Lombok Utara ternyata menyimpan banyak situs sejarah dan panorama alam yang indah untuk dikembangkan menjadi wisata agrowisata dan budaya. Begitu juga Kabupaten Lombok timur, seperti kecamatan Sembalun, Masbagek, Aikmel, Suela, Wanasaba dan beberapa kecamatan lainya mempunyai alam dan lingkungan yang masih asli dan terjaga yang dapat digunakan menjadi sebuah kawasan tujuan wisata, dan dapat dikembangkan menjadi sebuah kawasan Agrowisata. Dengan pengembangan desa agrowisata dan partisipasi stakeholder Pariwisata yang akomodatif dan aktif serta kolaborasi yang harmonis dari masyarakat, Pihak Swasta (Businness Side), Pihak Akademisi (Academic), dan Pihak Pemerintah (Government) tentu akan mempunyai andil dalam upaya mendukung tercapainya sasaran kebijakan pemerintah Kabupaten Lombok Timur dan Lombok Utara dan Kabupaten lainya guna meningkatkan pertumbuhan ekonomi dan pemerataan hasil-hasil pembangunan termasuk pengentasan kemiskinan, memberikan lapangan kerja, penghasil produk eksport serta pemeliharaan sumber daya alam dan kelestarian Lingkungan Hidup dan sekaligus mendukung upaya geopark Rinjani Lombok menuju Unesco Global Geopark (UGG). Di wilayah Kabupaten lombok Timur, Lombok Tengah dan Lombok Utara beberapa sudah mengembangkan berbarbagai tanaman buah, holtikultura dan beberapa tanaman unggulan lokal, hanya belum dikemas dan diusahakan secara maksimal. Oleh karena itu perlu adanya pengembangan daerah-daerah tersebut sehingga menjadi tujuan wisata. Beberapa hal yang dapat dilakukan seperti pengelolaan budidaya tanaman yang sesuai dan menjadikan sebagai unggulan daerah dan juga pengelolaan manajerial dari pengelola agrowisata tersebut. Sejak tahun 2016 sampai 2018 Sarjan dkk telah melakukan penelitian pengembangan benih kentang dan komoditas hortikultura unggulan seperti kentang, wortel, paprika, bawang 6 putih dan mentimun jepang di dataran medium dan pengembangan kampung strowbery, serta teknologi perbanyakan kentang dengan menggunakan stek pucuk. Penelitian tersebut dilakukan di 3 lokasi di pulau lombok yaitu Santong (Lombok Utara), Beriri Jarak dan Bebidas (Lombok Timur), dan Stiling (Lombok Tengah). Hasil penelitian tersebut telah diaplikasikan oleh petani di lokasi tersebut dan siap dikomersialkan. Kegiatan komersialisasi sangat penting dilakukan untuk pengembangan teknologi baru di masyarakat sehingga dapat memberikan manfaat dalam hal pemenuhan kebutuhan pangan. Tujuan kegiatan ini adalah untuk meningkatkan produksi hortikultura unggulan seperti wortel, kentang, mentimun jepang, dan bawang putih di dataran medium sehingga dapat menekan impor; mengembangkan potensi agroeduteknowisata (wisata dengan tujuan agrobisnis, edukasi dan teknologi pertanian) berbasis holtikultura dan tanaman unggulan lokal yang ada di wilayah kabupaten Lombok Tengah secara optimal, terencana, dan komprehensif. Berbagai produk hortikultura seperti wortel, kentang, paprika, timun jepang, bawang putih biasanya diproduksi di dataran tinggi. Produksifitas komoditas-komoditas tersebut masih belum optimal sehingga masih diperlukan impor. Untuk menekan impor, maka komoditas-komoditas tersebut perlu dikembangkan di dataran medium. Selain untuk pemenuhan produksi (tujuan agrobisnis), kedepannya kawasan usaha ini juga akan menjadi kawasan wisata baru, sarana edukasi dan teknologi.

Manfaat dari kegiatan ini yaitu untuk menciptakan lapangan kerja, meningkatkan pendapatan petani, membuka peluang agrobisnis di dataran medium. Dampak dari kegitan ini diharapkan mengurangi pengangguran, meningkatkan pendapatan masyarakat sekitar terutama petani lokal di kawasan lokasi kegiatan. Melalui kegiatan pendampingan ini diharapkan petani mengenal teknik budidaya, pnanganan pascapanen dan pemasaran komoditas unggulan, 
dan dalam jangka panjang Komoditas unggulan seperti kentang, wortel dan paprika diharapkan menjadi andalan untuk dipasarkan di kawasan wisata lainnya seperti di pantai Selatan Mandalika.

\section{Metode}

\section{Penentuan Lokasi Kegiatan dan Target Peserta}

Kegiatan ini dilaksanakan di Kawasan Desa Santong , Kabupaten Lombok Utara dan lokasi yang dipilih adalah Desa yang merupakan sentra hortikultura dataran medium yang pernah sebagai lokasi kaji terap budidaya kentang . Peserta terdiri atas petani dan kelompok tani andalan yang mempunyai pengalaman dalam budidaya tanaman kentang sebelumnya.

\section{Metode Pendekatan}

Metode yang digunakan dalam kegiatan ini adalah Metode Kaji Tindak (Action Research) dengan menerapkan pendekatan Program Tindak Partisipatif (Partisipatory Action Program) dari peserta melalui diskusi, dan kerja kelompok pada seluruh kegiatan. Tahapan dalam kegiatan ini meliputi tahapan persiapan, antara lain identifikasi masalah, kemudian survey pendasaran menggunakan metode deskriptif eksploratif. Tahapan pelaksanaan, diawali dengan pelatihan dengan teknik ceramah. Materi pelatihan yang disampaikan meliputi Teknik Budidaya Tanaman ; Pengenalan Organisme Pengganggu Tanaman kentang , serta Teknik-teknik Pengendalian Organisme Pengganggu Tanaman.

\section{Penilaian/evaluasi}

Penialaian terhadap kegiatan pengabdian pada masyarakat ini dilakukan dengan berpedoman pada:

1. Kesesuaian antara topik action research yang dilaksanakan dengan keadaan lokasi kegiatan.

2. Kehadiran dan partisipasi para peserta (sasaran) terhadap setiap kegiatan sejak dari persiapan sampai berakhirnya kegiatan mencerminkan keinginan dari peserta untuk mengetahui dan mengadopsi teknologi yang diperkenalkan oleh Tim pelaksana.

3. Sikap dan tanggapan dari para peserta terhadap kegiatan yang dilaksanakan.

\section{Hasil dan Pembahasan}

\section{Kegiatan Penyuluhan dan Sosialisasi Kegiatan}

Pada tahap sosialisasi kegiatan dalam diskusi acara penyuluhan sangat menarik karena langsung dihadiri oleh Kepala Dinas dan jajaranya sebagi bentuk komitmen yang kuat untuk mendukung kegiatan pendampingan tersebut. Hal ini dibebakan karena sinkron dengan keinginan dan kebijakan Pemerintah daerah Kabupaten Lombok Tengah untuk menjadikan kawasan Aiq Meneng (termasuk Kecamatan Batukliang Utara) sebagai pusat produksi hortikultura (sayur dan buah buahan) untuk menyokong pembangunan pariwisata di Lombok Tengah. Demikian juga para penyuluh menunjukkan antusisnya pada acara diskusi yang dibuktikn dengan banyaknya pertanyaan dari mereka terutama terkait dengan teknik budidaya komoditas yang sebelumnya tidak pernah diusahakan di lokasi tersebut. Dari peserta kelompok tani juga banyak yang tertarik mendengarkan penjelasan dari tim maupun kepala Dinas sehingga mereka menhadiri acara dengan penuh dari awal sampai akhir dengan pertanyaan pertanyaan yang sangat menarik, termasuk tentang teknik pembibitan, penanaman dan pemeliharaan tanaman sampai penanganan pasca panen dan pemasaran. Oleh karena banyaknya pihak yang tertarik pada kegiatan ini baik kepala dinas, penyuluh dan petani menjadikan tim optimis untuk melaksanakan pendampingan pengembangan komoditas hortikultura unggulan di lokasi kegiatan. Pada kegiatan penyuluhan disepakati akan dilakukan demplot pennaman tanaman kentang, wortel, paprika, bawang putih dan mentimun jepang yang sebenarnya menurut beberapa peserta pernah dicoba dilokasi dengan pertumbuhsn ysng cukup baik. Di tambah dengan pengalaman tim yang telah melakukan penelitian produksi benih kentang dibeberapa tempat kawasan medium dengan hasil yang cukup baik. Namun kendala yang disampaikan oleh peserta adalah selama pengalaman mereka, tanaman sering diserang oleh berbagai hama dan penyakit yang sult dikendalikan. 


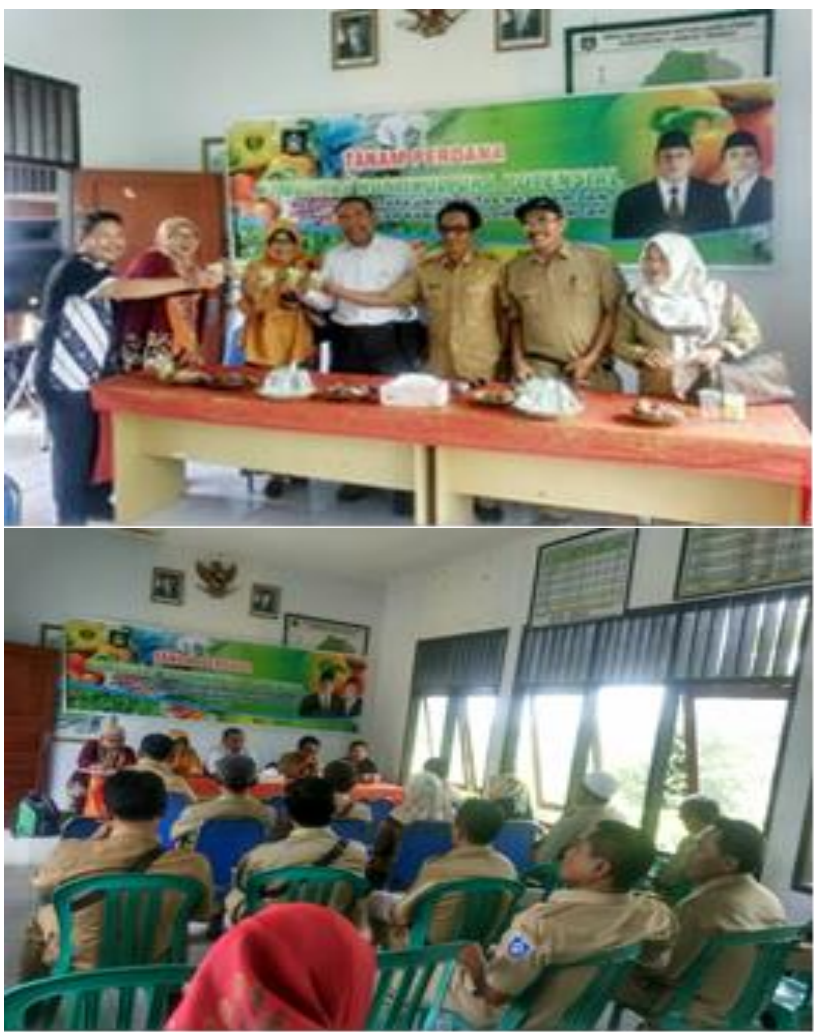

Gambar 1. Penyuluhan dan Sosialisasi kegiatan pendampingan oleh Tim dan Mitra (Dinas Pertanian Kabupaten Lombok tengah)

\section{Kegiatan demplot}

Pada tahap persiapan lahan tanam dilakukan oleh petani di lokasi UPT desa Stiling dengan pendmpingan oleh tim dan penyuluh setempat dengan membuat mengolah lahan menggunakan traktor, kemudian dibuat petak sesuai dengan jenis komoditas yaitu kentang, wortel, paprika, bawang putih dan mentimun jepang. Kemudian dilakukan pemupukan pupuk dasar menggunakan Petroganik : 3 Ton/ $\mathrm{Ha}$ atau $90 \mathrm{Kg} / 3$ are, NPK : $300 \mathrm{Kg} / \mathrm{Ha}$ atau $9 \mathrm{Kg} / 3$ are dan SP36 : $300 \mathrm{Kg} / \mathrm{Ha}$ atau $9 \mathrm{Kg} / 3$ are, dan pupuk susulan dilakukan setelah tanaman berumur 30 hari untuk tanaman kentang, wortel dan bawang putih menggunakan Pupuk yang digunakan sebagai pupuk susulan adalah NPK dengan dosis 350 $\mathrm{Kg} / \mathrm{Ha}$ atau $11 \mathrm{Kg} / 3$ are dan $\mathrm{ZA}$ dengan dosis 350 $\mathrm{Kg} / \mathrm{Ha}$ atau $11 \mathrm{Kg} / 3$ are .Sedangkan untuk tanaman timun jepang dan paprika hanya dipupuk menggunakan pupuk kandang sebanyak 10 ton per ha pada saat seminggu sebelum tanam.

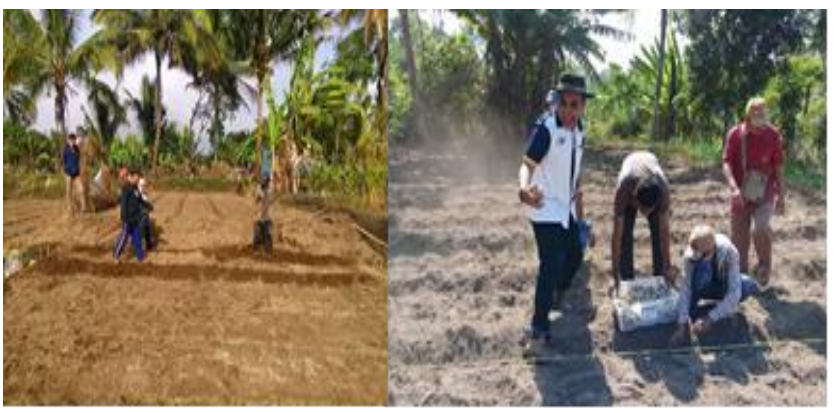

(A)

(B)

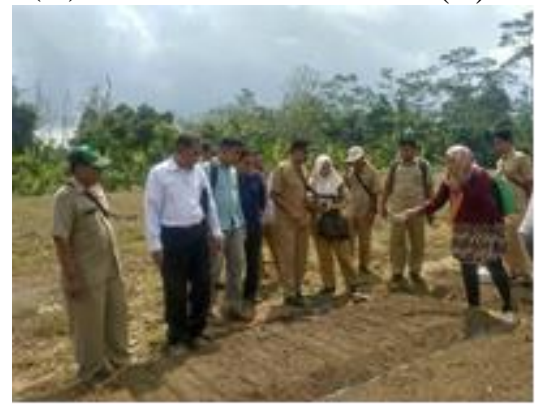

(C)

Gambar 2. Persiapan lahan dan Pembuatan petak demplot tanaman (A), Penanam Kentang G2 varitas Granola. L (B) dan penanaman Wortel (C)

Pengairan lahan dilakukan seminggu sekali. Hal ini dikarenakan kondisi tanah pada lahan penanaman bersifat lempung berpasir sehingga memiliki porositas yang tergolong tinggi. Pengairan dilakukan pada malam hari. Pengairan dihentikan ketika tanaman kentang mendekati usia panen (2 minggu sebelum panen).

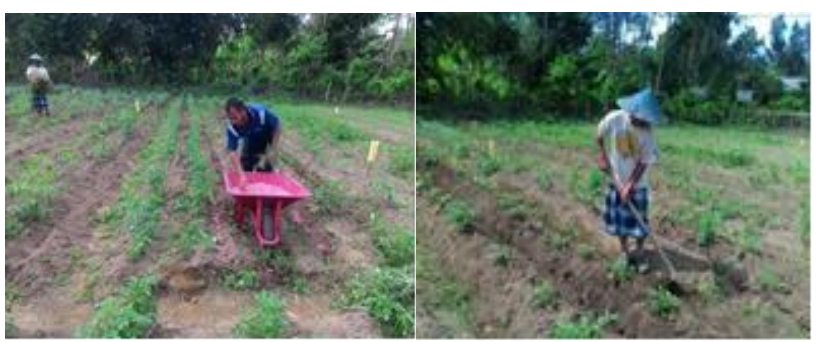

(A)

(B)

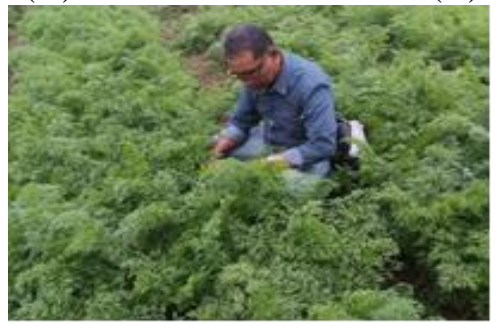

(C)

Gambar. 3. Pemupukan susulan tanaman kentang (A), Pembumbunan (B) dan Pengamatan Pertumbuhan Wortel (C) 
Penyiangan dilakukan pada saat tanaman kentang berumur 3 MST bersamaan dengan kegiatan pembumbunan, selanjutnya seminggu kemudian dilakukan pemupukan susulan. Pada ini saat dilakukan penyiangan dan pembumbunan harmenggaggus berhati hati agar tidak mengganggu perakaran tanaman dan umbi yang baru terbentuk. Tujuan pembubunan ini di samping untuk memperbaiki struktur tanah disekitar perakaran tanaman agar umbi berkembang dengan baik, juga untuk tujuan pengaturan saluran irigasi dan drainasi. Tujuan lainnya untuk mengkondisikan tanaman agar tetap tegak. Selain itu, kegiatan ini juga dilakukan untuk menggemburkan tanah disekitar tanaman.

Pemeliharaan tanaman yang sangat penting pada budidaya tanaman hortikultura dataran medium adalah pengendalian hama dan penyakit tanaman. Pengendalian hama pada tanaman dilakukan satu kali seminggu dimulai sejak tanaman berumur 1 minggu. Pengendalian hama tersebut menggunakan Metharizium saat umur 1 dan 6 MST, serta menggunakan BiVi saat umur 2, 3, 4, 5, 7, 8, 9, 10 MST. Pengendalian penyakit pada tanaman kentang dilakukan sejak tanaman berumur 7 MST. Hal tersebut dilakukan untuk mengantisipasi penyakit bor minyak yang akan menyerang pada tanaman kentang saat kondisi lingkungan lembab. Pengendalian penyakit tersebut menggunakan Antracol.

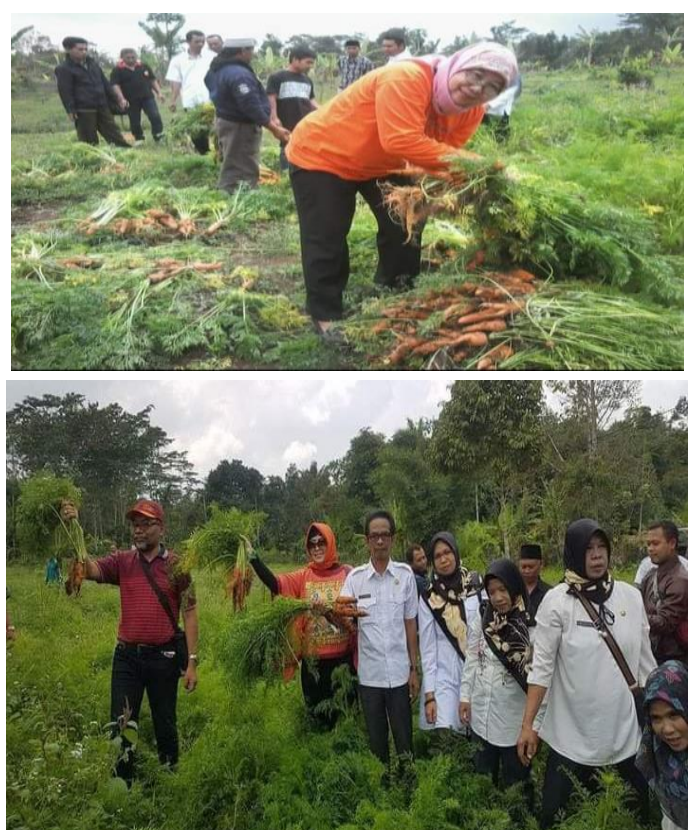

Gambar 4. Panen Raya Wortel bersama Kepala Dinas Pertanian Kabupaten Lombok Tengah
Panen dilakukan apabila umbi kentang telah siap untuk dipanen. Umbi yang siap dipanen ditandai dengan kulit umbi tidak terkelupas saat dipencet atau pada umur tanaman 110 hari. Sedangkan tanaman wortel dipanen saat umbi sudah mengeras berwarna kuning/orange yang bernas atau pada umur tanaman 90 hari setelah tanam, paprika pada umu 60 hari, timun jepang mulai pada umur 32 hari setelah pindah tanam, dan bawang putih pada umur 95 hari setelah tanam seperti pada gambar 4 dan 5 .

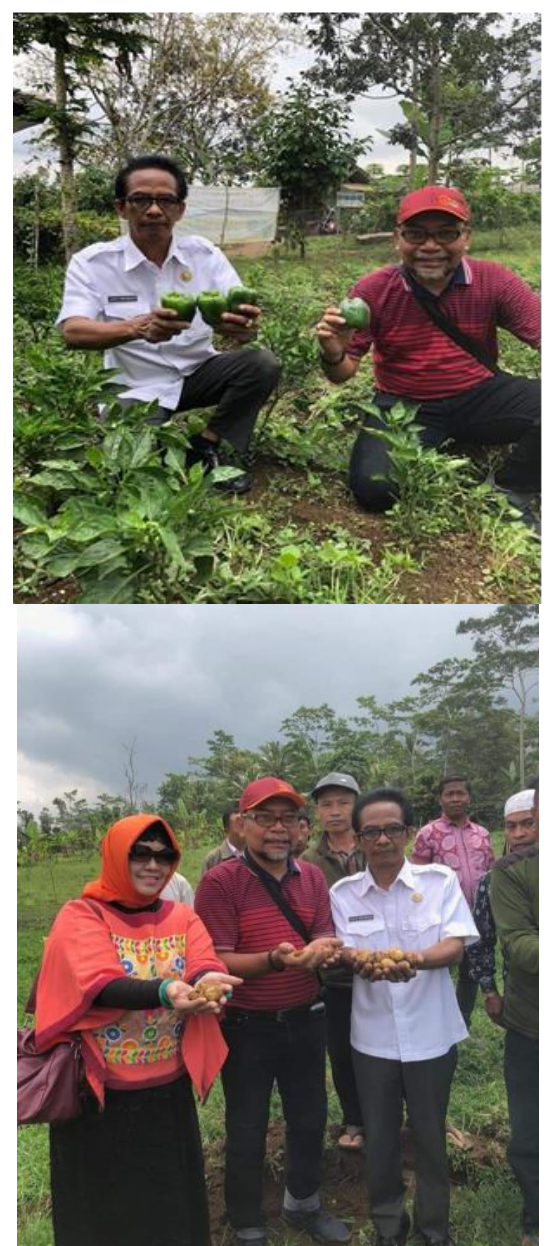

Gambar 5. Panen Raya Kentang dan paprika bersama Kepala Dinas Pertanian Kabupaten Lombok Tengah.

Dari empat komoditas yang dicoba pada kegiatan ini seperti ditunjukkan pada gambar 6 di bawah, wortel merupakan tanaman yang paling baik pertumbuhannya sampai panen hasil umbi wortel yang kualitasnya sangat baik, diikuti oleh paprika dengan buah yang cukup baik. Sedangkan mentimun jepang dalam pertumbuhannya diganggu oleh hama kumbang Ephilacna sp, sehingga 
pertumbuhan terganggu yang menyebabkan hasil buahnya kurang maksimal. Demikian juga dengan bawang putih pada tahap pertumbuhan awal terkendala oleh intensitas hujan yang tinggi sehingga pertumbuhan vegetatif tergganggu yang menyebabkan pengisian umbi tidak sempurna, walaupun masih bisa dipanen, namun tidak mendapatkan hasil yang baik. Tanaman kentang pada awal petumbuhannya cukup baik, tapi pada saat memsuki fase pembentukan dan pengisian umbi terjadi intensitas hujan yang tinggi, sehingga mengganggu pengisian umbi secara sempurna. Di samping itu akibat intensitas hujan yang berkabut menyebabkan tanaman kentang terserang penyakit embun upas, dan beberapa tanaman juga terserang penyakit busuk daun yang biasa disebut hawar daun (late blight), yang dsebabkan patogen Phytopthora infestans (Mont). Akibatnya tanaman kentang menghasilnya umbi yang kurang naksimal secara kuantitatif dengan umbi kecil kecil. Walapun masih sangat baik digunakan sebagian sebagai benih untuk penanaman selanjutnya karena yang ditanam adalah G1 yang menghasilkan G2 untuk konsumsi selanjutnya. Sedangkan umbi yang agak besar langsung dimanfaatkan sebagai kentang konsumsi oleh kelompok tani.

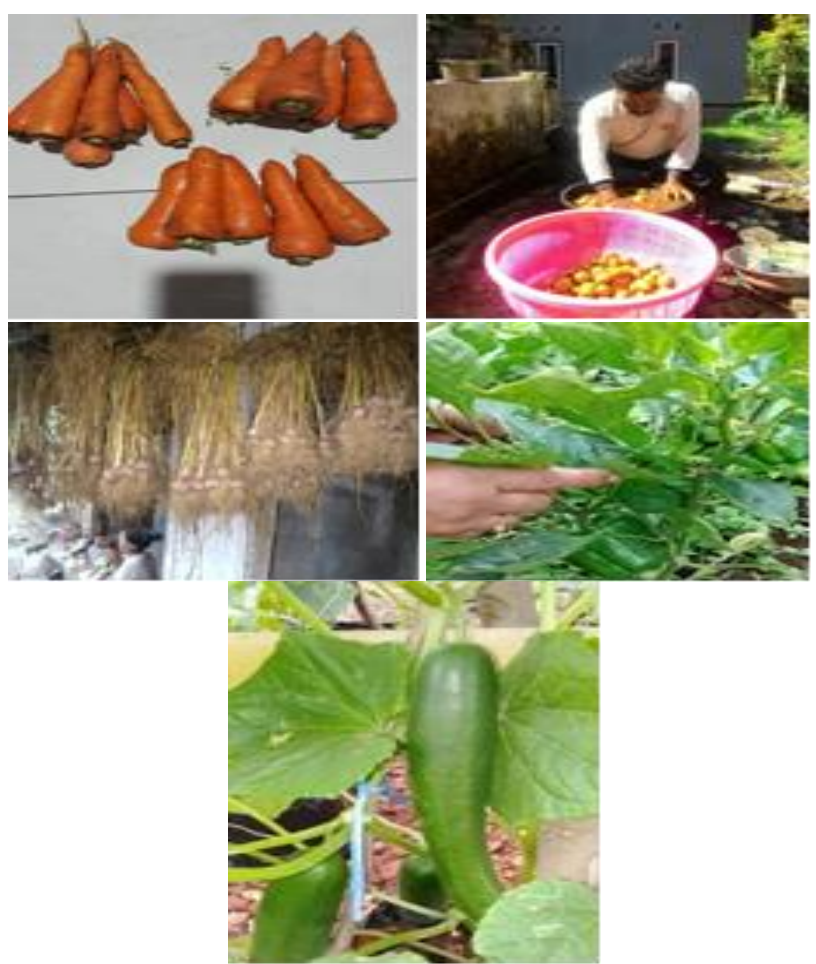

Gambar 6. Hasil panen demplot tanaman Kentang, wortel, paprika, bawang puih dan timun jepang.
Beberapa hasil kegiatan pendampingan ini seperti kentang dan wortel diikutkan pada expo hasil Pertanian yang dilaksanakan oleh Dinas Pertanian Kota Mataram yang bergabung dengan hasil teknologi Fakultas Pertanian Universitas Mataram seperti terlihat pada gambar di bawah ini.
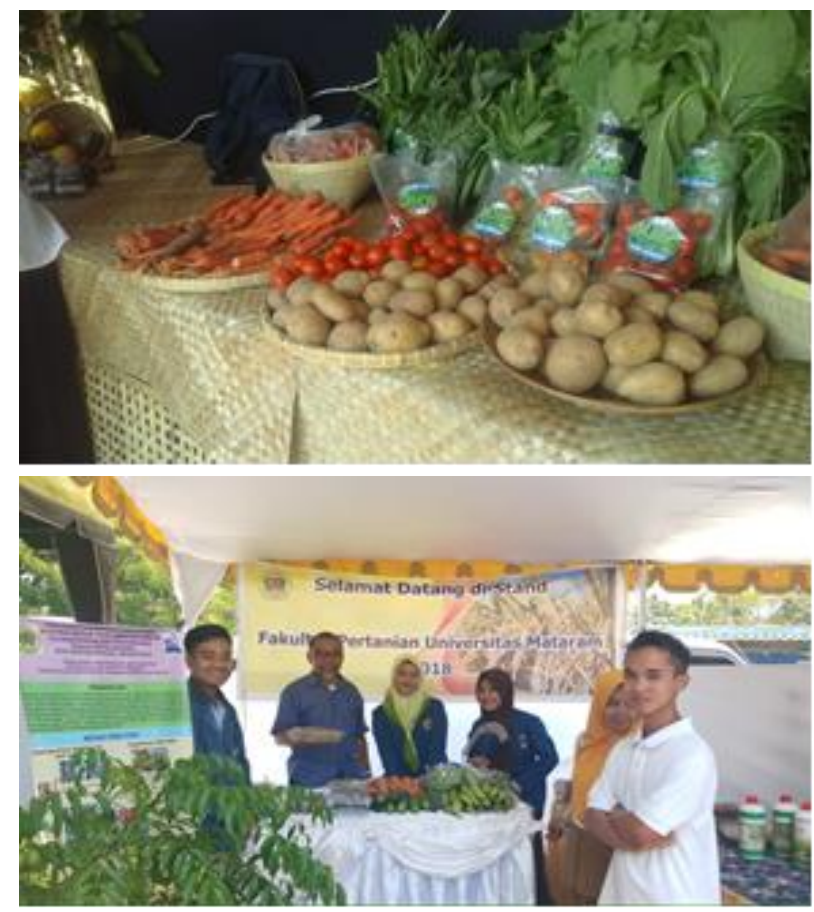

Gambar 7. Expo hasil demplot pada acara expo di Kota Mataram.

Secara keseluruhan dapat dikatakan bahwa kegiatan pendampingan pengembangan hortikultura unggulan di dataran medium Desa Stiling, Lombok Tengah cukup berhasil yang dibuktikan dengan terlibatnya Kepala Dinas Pertanian dan jajaranya, mulai kepala Bidang, kepala UPT dan para penyuluh dalam rangkaian kegiatan di awal sampai ahir, baik saat penyuluhan maupun saat demplot budidaya. Demikian juga dengan keterliatan para anggota kelompok tani yang sangat aktif selama kegiatan dan ada 4 orang yang selanjutnya ingin mencoba melanjutkan penanaman secara mandiri pada musim berikutnya. Dari hasil pemantauan selama prtumbuhan tanaman sampai panen dapat dikemukkan beberapa kendala antara lain, musim penanaman yang kurang tepat saat musim hujan dengan intensitas yang tinggi untuk tanaman kentang dan bawang putih, tetapi cukup baik untuk tanaman wortel, paprika dan timun jepang. Kendala utama lainnya adalah adanya serangan Organisme Penggagu Tanaman baik Hama maupun Penyakit 
terutama pada tanaman kentang dan bawang putih. Oleh karena itu pada masa masa selanjutnya perlu mempertimbangkan kendala di atas dengan menanam pada saat yang tepat dan melakukan upaya pengendalian hama penyakit secara serius melalui pemantauan yang intensif dan menggunakan pestisida yang tepat dan efektif apabila diperlukan.

\section{Kesimpulan}

1. Kegiatan Pendampingan Pengembangan Komoditas Hortikultura di dataran Medium Desa Stiling, Lombok Tengah sangat didukung oleh pemangku Kebijakan, Kepala Dinas Pertanian dan oleh Kelompok Tani setempat.

2. Tanaman Kentang, wortel, bawang putih, paprika dan mentimun jepang dapat tumbuh baik di dataran medium Stiling, Lombok Tengah.

3. Petani peserta telah mendapatkan pengetahuan dan keterampilan teknik budidaya tanaman yang dicoba pada kegiatan ini yaitu budidaya kentang, wortel, bawang putih, mentimun jepang dan paprika.

\section{Ucapan Terima Kasih}

Diucapkan terima kasih kepada Kepala Dinas Pertanian Kabupaten Lombok Tengan bersama jajarannya yang telah membantu dan memfasilitasi kegiatan pendampingan ini.

\section{Daftar Pustaka}

AAK. 1992. Petunjuk Praktis Bertanam Sayuran. Kanisius: Yogyakarta.

Badan Pusat Statistik. 2015. Badan Pusat Statistik Indonesia. Http:// www.bps.go.id. Diakses pada [ 8 April 2015].

Abbas, Akmadi. (2007). "Karakteristik Fisik Wortel (Daucus carota L.) Terhadap Penanganan Pasca Panen dan Penerapan Quality Control". Teknik Kimia Kejuangan.13, (1), 15-18.

Ali, N.B.V., dan E., Rahayu, 2000.Wortel dan Lobak, Penebar Swadaya Jakarta.

BPSB TPH Provinsi NTB. 2015 http://diperta.ntbprov.go.id/data_base/kenta ng. htm. Diakses pada [8 April 2020].
Central International Potato. 1984. Potatoes for the Developing World. Lima, Peru.

Herawati, W. D. 2012. Budidya Sayuran. Javalitera. Jogjakarta.

Idawati. 2012. Pedoman Lengkap Bertanam Kentang,Langkah Mudah Budidaya Kentang dan Kiat Bisnis Olahan Kentang. Pustaka Baru Press. Jogjakarta.

Poerwanto, R. dan Susila, A.D. 2014. Seri 1 Hortikultura Tropika, Teknologi Hortikultura. Bogor. IPB Press

Rubatzky, Vincent E dan Mas Yamaguchi. 1995. Sayuran Dunia 1: Prinsip, Produksi dan Gizi Edisi Kedua. Penerbit ITB: Bandung.

Rukmana, R. 2002.Usaha Tani Kentang Didataran Medium.Kanisius. Yogyakarta.

Setiadi dan Surya Fitri Nurulhuda. 1993. Kentang: Varietas dan Pembudidayaan. Penebar Swadaya: Jakarta.

Sembel, D. T, 2014. Serangga-serangga Hama Tanaman Pangan, Umbi dan Sayur. Bayumedia Publishing, Malang.

Sinung, R. Basuki. 1989. Production Potato in Indonesia: Prospect for Medium Altitude Production (Eds J. W. T. Bottema et al.). CGPRT Centre, Bogor .

Wattimena, G.A. 2006. Prospek Plasma Nutfah dalam Mendukung Swasembada Benih Kentang di Indonesia. Direktorat Perbenihan dan Sarana Produksi. Ditjen Hortikultura, Departemen Pertanian, Jakarta.

Wibowo, S. 2007. Budidaya Bawang: Bawang Putih, Bawang Merah, Bawang Bombay. Jakarta: Penebar Swadaya. 